\title{
Catatan Editor:
}

\section{Wabah Corona dan Perencanaan Pembangunan di Indonesia}

Para pembaca Bappenas Working Papers yang budiman,

Rencana Pembangunan Jangka Menengah Nasional (RPJMN) 2020 - 2024 baru disahkan menjadi Peraturan Presiden Nomor 18 Tahun 2020 pada tanggal 14 Februari 2020 lalu. Dokumen ini menjadi pedoman pemerintah pusat dan daerah dalam melakukan perencanaan pembangunan pada kurun waktu 5 tahun ke depan.

Sementara itu perkembangan terkini dunia sedang berperang melawan virus corona (covid-19 atau sars cov 2) yang pada waktu itu menyerang dari asalnya di Wuhan - China, lalu ke negara-negara Asia (Jepang, Korea, Singapura, dan terparah di Iran), kemudian ke Eropa dengan wilayah terparah di Italia dan Spanyol, terbang ke Amerika, Australia, dan juga Indonesia yang ditemukan kasus pertama pada tanggal 3 Maret 2020. Praktis seluruh dunia kini sibuk mengerahkan semua sumber daya untuk mengatasi wabah ini.

Pembangunan di setiap negara terganggu. Semua negara merevisi APBN masingmasing dan memberikan alokasi dana yang besar dalam rangka mengatasi wabah corona ini. Mengingat penyakit yang datang melalui virus corona ini cukup mematikan (rata-rata sekitar $3-5 \%$ kematian dari jumlah orang yang tarpapar virus), obat paten belum ditemukan juga vaksinnya, maka pencegahan adalah tindakan terbaik yang harus dilakukan masingmasing negara.

Kebijakan umum yang harus dilakukan di tingkat masyarakat adalah kebijakan social and physical distancing (menjaga jarak dari kerumunan dan perorangan). Mengubah perilaku sosial masyarakat ini bukan pekerjaan mudah. Berbagai negara cukup susah menerapkannya, sebagaimana di Iran, Italia, Spanyol, dan di Amerika Serikat.

Kebijakan berikutnya yang menjadi alat utama pemerintah adalah lockdown (dalam Kamus Besar Bahasa Indonesia diterjemahkan karantina wilayah). Ada yang menerapkan karantina wilayah penuh, sebagian, hingga yang minimal dengan dipadu kebijakan pembatasan sosial melalui perilaku jaga jarak antar masyarakat. Ini diharapkan dapat memutus mata rantai penyebaran virus corona ini. Indonesia sendiri lebih memilih kebijakan pembatasan sosial berskala besar.

Di Indonesia, pembatasan sosial berskala besar melalui libur sekolah, penutupan tempat wisata dan hiburan, kantor-kantor dihimbau agar pegawainya bekerja di rumah, serta pembatasan-pembatasan lain yang ditujukan penuh untuk memutus mata rantai penyebaran virus corona.

Wabah corona ini juga memaksa semua negara mengoreksi rencana-rencana pembangunan dan pengembangan perekonomiannya. Target-target direvisi, asumsi-asumsi diperbaiki, dan perhatian penuh dialihkan pada penanggulangan wabah, sedangkan kebijakan pengembalian perekonomian dilakukan setelah masa tanggap darurat dinyatakan selesai.

Pemerintah pusat dan daerah di Indonesia juga sedang melakukan koreksi-koreksi terhadap rencana pembangunan yang telah ditetapkan dalam dokuman perencanaan maupun anggaran. Penyesuaian yang tepat dan kebijakan yang terukur dalam mengatasi wabah corona akan menjadi titik tolak melakukan perbaikan kembali (recovery).

Bappenas Working Papers pada edisi ini mengetengahkan beberapa artikel yang masih berhubungan erat dengan perencanaan dan kebijakan pembangunan. Ada 8 artikel kami sajikan. Yang pertama dari Oswar Mungkasa yang menulis artikel tentang kebijakan 
bekerja jarak jauh (telecommuting) yang cukup relevan tengan keadaan sekarang. Artikel kedua ditulis oleh Hanan Nugroho yang membahas kebijakan penyediaan energi di ibukota negara yang baru. Ketiga, Ahmad Ibnu Riza dan Athoillah Islamy mengetengahkan analisis spasial dan penggunaan lahan di area pantai di Kabupaten Batang - Jawa Tengah. Keempat, Dadang Solihin menulis artikel tentang bagaimana meningkatkan sumber daya manusia Perencana dalam perencanaan pembangunan jangka panjang. Kelima, Dinar Kharisma menulis ketimpangan akses di bidang kesehatan pengan fokus pada program Jaminan Kesehatan Nasional. Keenam, Pardomuan Robinson Sihombing dan Ade Marsinta Marsani menyajikan artikel tentang pengaruh tingkat pendidikan, kesejahteraan, dan penghasilan terhadap konsumsi rokok. Ketujuh, Andi Setyo Pambudi memberikan wawasan tentang pelaksanaan Dana Alokasi Khusus. Kedelapan, Rufita Sri Hasanah menulis artikel tentang. pemetaan keunggulan kompetitif dan spesialisasi di Indonesia. 1 - 2020 ini.

Demikian catatan editor Bappenas Working Papers untuk edisi Volume III Nomor

Semoga Indonesia mampu mengatasi wabah corona ini bersama-sama dan dalam waktu yang cepat dapat memulihkan kembali kondisi perekonomian.

Salam,

Muhyiddin

(Ketua Dewan Editor) 